\title{
The Contribution of School Governing Bodies in Promoting Democracy in South African Schools: The Current Trends
}

\author{
Vusi Mncube \\ University of South Africa \\ Mncubvs@unisa.ac.za \\ Renuka Naidoo \\ ren@primarymath.net
}

\section{Doi:10.5901/mjss.2014.v5n3p484}

\begin{abstract}
This paper reports on a qualitative study that adopted an interpretive paradigm. The study sought to understand the experience and functioning of the school governing body as a tool to promote democracy in schools. Data were gathered through qualitative data collection methods, namely observations, semi-structured interviews and document reviews. The findings revealed that the principals embraced the existence of the following components of democracy in their schools: shared decision-making; acknowledgment of the rights of individuals; and the need for representation, participation and equality. Two structures for promoting democracy were found to be in existence in both schools, namely School Governing Bodies and Representative Councils for Learners. These structures were found to be functioning effectively and they were contributing to democracy in the schools. However, although learners' voices were represented at both schools, learner participation in crucial issues in both schools was limited. The study recommends that all teachers, learners and parent representatives on SGBs be trained in skills such as deliberation; debate, dialogue and conflict management.Furthermore, training or capacity building related to advocacy skills and leadership development should be provided for all members of the SGB, including the teachers. Better learner, parental and staff involvement in school policy and decision-making will lead to more genuine community involvement and more effective and efficient school management.
\end{abstract}

Keywords: Democracy, education, equality, leadership, learners, management, parents, participation, representation, school governance

\section{Introduction and Background}

Authoritarian forms of organisation are evident in most schools throughout the world. Harber (1997b:39) states:

Schools in most parts of the world are presently essentially authoritarian institutions. Power over curriculum and management is hierarchically organised with the Ministry at the top, the head-teacher next and the teachers third in terms of control. Pupils play little part in school processes other than as receivers of rules and information.

In Africa, a hierarchical organisation within schools still prevails and an authoritarian form of school organisation on the continent is clearly observable at classroom level. Karlsson and Mbokazi (2005:11) contend that school management in some schools in KwaZulu-Natal is characterised by "formality and authoritarianism". In this regard Datta states:

In most African countries the classroom is highly structured in terms of the formal distribution of space. The teacher in the classroom exercises unquestioned authority in such matters as seating arrangement and movement ... but also controls communication channels within the group. ... This kind of classroom environment determines the political orientation of pupils but forced conformity to an authoritarian system throughout childhood and early adolescence ... is likely to encourage passive acceptance of authority in later years (Datta, 1984:40).

Schools in Africa are still bureaucratically organised and teach impersonal, contractual values and relationships that typify the transition from an agricultural to an industrial society (Harber, 1997b). Corroborating this view, Grant (2006:525) refers to the continued existence of a "hierarchical school organization controlled by autocratic principals" at some schools in South Africa. 
During the apartheid era, South African schools operated around a system of authoritarianism that emphasised a rigid, top-down or hierarchical management approach. Principals were compelled to follow instructions from the Department of Education (DoE). The advent of democracy prompted the democratisation of the education system which is embedded in the South African Schools Act 84 of 1996 (SASA). In the preamble to the Constitution of the Republic of South Africa (RSA, 1996a), a new set of values and a move away from the past are emphasised so as to "establish a society based on democratic values, social justice and fundamental human rights [and to] lay the foundations for a democratic and open society" (RSA, 1996a:1).

Dewey (1916) asserted that if individuals were to pursue and establish a democratic way of life, they should be afforded opportunities to learn the meaning of that way of life. It follows therefore that to achieve a democratic society, it is necessary to create democratic schools. Numerous scholars (Dewey, 1916; Apple \& Beane, 2007) have similar ideas regarding the correlation between education and democracy. In their impassioned defence of more democratic schools, researchers have made philosophical and theoretical claims, saying that a salient feature of democratic schools is democratic school governance which is associated with site-based management. There is growing interest nationally and internationally in democratic school governance and its implementation.

Various studies have already been conducted concerning school governance in the democratisation of education in the RSA (Mncube, 2009; Tsotetsi, Van Wyk \& Lemmer 2008; Bush \& Heystek, 2003; Van Wyk, 2004). The current study adds to the growing body of knowledge by investigating stakeholder notions of democratic schools. With the exceptions of Mncube (2009) and Bush and Heystek (2003), the above studies were based on theoretical or conceptual papers. Moreover, most studies used teacher participants to investigate learner attitudes and perceptions. Conversely, this study gauged the views of all the stakeholders of the school, including learners and parents. This study was based on new, empirically grounded knowledge about democratic schools. This knowledge was both descriptive and conceptual. The study also deviated from other studies by triangulating the data collected through interviews, documents and observations. Consequently, it is hoped that the study will make a modest significant contribution to issues of democratic schooling nationally and internationally.

As an emerging economy, South Africa has to make every effort to attract donors and investors by demonstrating and assuring them that it is worth investing in South Africa. This will only happen if transparency, stability, and openness prevail. Spreading democratic values through school governing bodies therefore has the potential to produce a democratic citizenry which, in the long run, will attract powerful investors and donors to South Africa.

The Department of Education contends that a key goal of education in South Africa is democracy:

The realisation of democracy, liberty, equality, justice and peace are necessary for the full pursuit and enjoyment of lifelong learning. It should be the goal of education and training policy to enable a democratic, free, equal, just and peaceful society to take root and prosper in our land, on the basis that all South Africans without exception share the same inalienable rights, equal citizenship, and common national destiny, and that all forms of bias (especially racial, ethnic and gender) are dehumanising (South Africa Department of Education, 1995:22).

From this it follows that an effective school in South Africa is one that operates democratically and promotes democracy in the broader community.

\subsection{Structures for promoting democracy in South African schools}

In South Africa two main structures exist to promote democracy in schools and the wider society. These are the School Governing Body (SGB) and the Representative Council for Learners (RCL). The functions and responsibilities of both bodies are clearly stated in relevant guidelines and legislation.

\subsection{The School Governing Body (SGB)}

This section draws mainly from research done by Mncube, Harber and Du Plessis (2011). The South African Schools Act (SASA) No. 84 of 1996 (RSA, 1996c) followed on from the White Paper on the Organisation, Governance and Funding of Schools (RSA, 1996c). SASA mandates all public state schools in South Africa to have a democratically elected SGB constituted of teachers, non-teaching staff, parents and, in the case of secondary schools, learners. The functions of the SGB include recommending the appointment of educators and non-educator staff and determining both the language policy of the school and the school fees. In addition, these responsibilities suggest that SGBs should include parents and learners that are well informed about issues of school governance and the legal requirements stipulated in SASA. By 
enacting SASA, the South African government aims to foster a school governance structure that involves all stakeholder groups in education in order to promote democratic values such as tolerance, rational discussion and collective decisionmaking (Department of Education, 1997).

In a South African SGB, parent members are required by law to form a majority and one parent must hold the chair (Mncube, 2007:136-137; Mncube, Harber \& Du Plessis, 2011). This gives power and a voice to parents and is a way in which issues of democracy and social justice can be advanced in a country historically weighed down by racism, oppression and authoritarianism.

\subsection{Representative Council for Learners (RCL)}

The following section draws mainly from Mncube and Harber's (2013) research.

SASA mandates secondary school learners who are members of a representative council of learners $(R C L)$ to participate in school governance as members of the SGB. Participation by learners in governance processes provides the necessary space for them to acquire democratic capacity and leadership skills (RSA, 1996c). According to the Department of Education (RSA, 1999, cited in Mncube \& Harber, 2013:3), the main responsibilities of the RCL are as follows:

a) To act as an important instrument for liaison and communication;

b) To meet at regular intervals as determined by its constitution to consider ideas, suggestions, comments and complaints received from its constituency; and

c) To give feedback after every meeting to the learners they represent.

Each RCL is responsible for drafting their own constitution which must be approved by the teachers in the school. In addition, members of RCLs act as representatives of fellow learners on SGBs, assist in maintaining order by using the approved school rules, and set a positive example of discipline, loyalty, respect, punctuality, academic thoroughness, morality, cooperation and active participation in school activities. Furthermore, they are responsible for promoting good relations among the learners themselves and among the learners and staff, the school and the community, and the school and parents. Finally, the members have a duty to promote responsibility and leadership, to support the educational programme of the school and to maintain and refine school traditions (Mncube \& Harber, 2013:3).

\subsection{The Theory of Democracy in Education}

Democracy is understood to be many things and presents in different forms with somewhat different implications for education. Dewey (1916:87) viewed democracy as "a mode of associated living of conjoint communicated experience." In other words, for him democracy was linked to the idea of living together, with emphasis on communicative interactions and the sharing of experiences. Dewey's conception of democracy can be interpreted as a social and moral ideal as well as a form of social organisation in which individuals realise that they are interconnected and so learn by working with others (Dewey, 1916). He believed that it was necessary to consider one's own actions in relation to the actions of others and that democracy [was] allied with "humanism and faith in the potentialities of human nature". He stated that democracy meant the belief "that humanistic culture should prevail" (Dewey, 1939:124). In an essay, Dewey (1939) associated democracy with humanism and a belief in the inherent capabilities of individuals. In contrast, Talisse (2007) explains that Deweyan democracy is not only strong but deep, as it both prescribes a set of dispositions and attitudes that individuals should embody and also provides a model of institutional design.

O'Hair, McLaughlin and Reitzug (2000) present the notion of democracy as being associated with humanism. They add that democracy is a way of living which involves the open flow and critique of ideas with an authentic concern for others and for the common good. Based on this concept Print, Ørnstrøm and Nielsen (2002) maintain that democracy is about tolerance, compromise, a willingness to listen to the views of others and to be influenced by their arguments, and an acceptance of the attitudes and opinions of others.

This paper concurs with authors who maintain that democracy extends beyond elections and government structures and must be a way of life. Democracy is seen from the social perspective adopted by John Dewey and is regarded as a way of living which involves relating to and interacting with others in the community. Democracy is about infusing democratic principles into people's daily lives so that these principles become a way of life which establishes a democratic culture. However, within this social concept of democracy, inclusiveness and collective decision-making are essential. Other researchers add that democracy is more than just a political system. They argue that it is a way of relating to, working with and critically engaging with other citizens (Frank \& Huddleston, 2009; Goodlad, Mantle-Bromley 
\& Goodlad, 2004; O'Hair et al., 2000). This implies that democracies cannot survive without people participating in them.

For the purposes of this paper, the idea of a representative democracy as opposed to other forms of democracy is embraced. A representative democracy is an indirect democracy involving a system that embraces elected individuals who undertake to represent the interests and/or views of the people (Held, 2006). This is opposed to a direct democracy where the notion of representation involving elected individuals representing a larger group of individuals is associated with modern democracy. Carr (2008b) associates representative democracy with thin democracy and Young (2000) cautions against assuming that representative democracy is incompatible with deep or thick democracy. If representative democracy is confined to thin democracy, it follows that "large-scale mass societies are incompatible with thick democracy" (Young, 2000:8). Adopting a similar stance to Carr (2008b), the researchers that representative democracy can be aligned with thin democracy and has the potential to move towards thick or deep democracy.

\section{Research Problem and Questions}

The study aimed to garner data about people's experiences of the functioning of SGBs as a tool to promote democracy in schools. The study attempted to answer the following research question:

Do the views of secondary school learners, teachers and parents support the notion that their schools are lead and governed within the paradigm of deliberative democracy?

\section{Research Design and Methods}

This report stems from a qualitative study located within an interpretive paradigm. Within the parameters of qualitative research, a case study approach was adopted since it allows for an in-depth study of the phenomenon being investigated. This qualitative study used the following methods of data collection: observations, semi-structured interviews and document reviews. The principal, three parents, three teachers and three learners were interviewed at each of two purposively selected schools. Observations provided the opportunity to see and hear how democratic practices and processes unfolded in the schools. Face-to-face semi-structured interviews allowed the researcher to gather descriptive data in the respondents' own words. Documents were also used to supplement the collection of data.

\section{Sample}

The study employed convenience sampling of two secondary schools that were chosen on the basis of them being perceived as operating democratically by critical friends. Red Star Secondary School and Excel Secondary School (pseudonyms) both reflected some of the characteristics of democratic schools.

\section{Data Analysis}

Data analysis is the process of bringing order, structure and meaning to a mass of collected data. The data consisted of notes taken during the interviews that were conducted and transcripts of these interviews. These were analysed according to the phenomenological steps proposed by Giorgi, Fisher and Murray (1975) as cited in Mncube and Harber (2010).

\section{Ethical Issues}

All relevant ethical considerations such as voluntary participation, choice to withdraw, and confidentiality were discussed with the participants prior to the interviews and completely adhered to.

\section{Discussion of Research Findings}

\subsection{Structures for promoting democracy in schools}

As mandated by South African Schools Act 84, 1996 (SASA) both an SGB and RCL, as the two main structures aimed at promoting democracy in South African schools, were functioning within the two schools under study. This is in line with the reviewed literature. These structures were found to be functioning effectively and they were contributing to promoting 
democracy. SASA mandates secondary school learners who are members of the RCL to participate in school governance as members of SGBs. SASA legitimises the SGB as a democratic structure with parent, teacher and learner representatives. Both schools sampled in this study had fully functioning SGBs. Dimmock (1995) contends that a fundamental characteristic of a democratic school is the existence of appropriate decision-making structures and processes within its system.

With regard to democratic processes, the respondents at both Red Star Secondary School and Excel Secondary School made reference to collective decision-making, collaboration and voting. Moreover, inclusion of learners' voices is essential to democratic processes. However, the interviews and observations of SGB meetings at both schools revealed that although learners were present at SGB meetings, their actual participation in crucial issues was limited. Surprisingly, although the process of voting was used, the respondents did not view voting as the most important feature of a democratic school.

A learner representative at Red Star Secondary felt that with regard to governance at the school, "...there's a lot of working together - collaboration and basically just working as a team." At Excel Secondary School, a parent representative said, "All stakeholders are encouraged to participate in the governance of the school." Our observations of the SGB meetings at both schools allowed us to conclude that these meetings were characterised by openness, respect and the sharing of ideas, specifically with regard to the teachers, parents and the principal. This concurs with Singh's (2006) findings when he reported that at the core of shared school governance are virtues that include sharing, openness, trust and respect of others. The principal at Red Star Secondary School explained:

My role in school governance has therefore been mainly that of facilitator and co-leader. My task has been mainly to empower stakeholders to function effectively for the benefit of the community. This would then translate to democracy in action.

The principal saw himself as working together with others and his role was primarily to facilitate. The principal at Excel Secondary School had a similar attitude. He stated:

...you have a chairperson of a governing body and the chairperson leads the governing body. The people play their roles and you support those people. You encourage, develop, tutor, and mentor the people who are playing these roles.

From the principals' responses it was deduced that they believed that their role was to guide and support the various stakeholders. Both respondents suggested that they understood the role and functions of the SGB, which implies a move away from traditional school governance that Squelch (1999:128) refers to as "hierarchical and authoritarian in nature". However, a parent representative at Excel Secondary School was critical of the principal's non-democratic practices as he stated, "At times he [the principal] tends to dominate the SGB meetings". On the contrary, our observation of two staff briefings and an SGB meeting did not confirm this view. In both the schools parents chaired the SGB meetings. At Red Star Secondary School the principal did very little talking and at Excel Secondary School parents turned to the principal for guidance with regard to a sensitive issue pertaining to a looming teachers' strike.

The document review, observations and interviews revealed that the schools had school governing bodies comprising individuals that represented the various stakeholders. However, we noticed that in each school there was only one female parent representative on the SGB. When questioned about this, the secretary at Red Star Secondary School informed us that the second female representative "had dropped out" due to difficulties to attend meetings. At both the schools the participants felt that school governance was definitely shared. Shared school governance, according to Singh (2006), is a more democratic form of school governance. In describing his role in school governance, the principal at Red Star Secondary School stated that he adopted a democratic style of governance.

Mncube (2007) adds that SGBs assist in spreading democratic principles in schools and society and says that democratically governed schools honour participation, adequate representation, tolerance, deliberation, dialogue and rational discussion which lead to collective decision-making.

However, as stated earlier, we witnessed minimal participation by the learner representatives at the SGB meetings. Even one principal acknowledged that more could be done to include learner representatives in deliberations. Drawing on Hart's (1992) ladder of learner participation (cited in Whitty \& Wisby, 2007), it can be concluded that these learners were probably consulted and informed, but they were not involved in shared decision-making processes with the adults. In fact, written documents as well as the interviews revealed persuasive evidence that the learners were consulted only on minor issues. In an earlier study, Mncube and Harber (2009) explored the learner voice in South African schools and concluded that both parents and learners seem to be excluded from policy formulation. They made 
specific reference to the exclusion of parents and learners in the formulation of the school code of conduct (Mncube \& Harber, 2009). At Red Star Secondary School the teacher representative explained:

\begin{abstract}
However, I must emphasise that the learners are represented on the SGB and issues are often discussed with them. Maybe I should be including them more. I don't think I actually consult them on many issues. I tend more to tell them what's going on. Major issues are sorted out by the teachers, the principal, management, and parents.
\end{abstract}

In essence, the teacher confirmed that learners were not consulted on all issues. This lack of active learner participation may perhaps be attributed to the fact that principals, teachers and parents are still stuck in a traditional mode of school governance practices. Harber (1997) argues that in the past learners played a minor role in decisionmaking. This argument is corroborated by Squelch (1999) who elaborates that in the past there was minimal participation by teachers, parents or learners. While not dismissing the fact that at both schools there was learner representation on the SGB, the emerging issue was minimal learner participation in shared school governance. There is a need to focus on the inclusivity of the learner voice in shared school governance. Essentially, there is a need to move away from the socalled culture of silence associated with learners that has been inherited from the past authoritarian educational system.

The parent representative at Red Star Secondary School provided more detail regarding the areas where learners provided input. These areas included classroom behaviour, examination etiquette and the problem of smoking. Bäckman and Trafford (2007) suggest that the inclusion of individuals in decision-making should not be limited to formal meetings. This implies that learners should be provided with avenues other than the formal SGB meetings to encourage shared decision-making. Learners should also be involved in shaping the policies used in school as this would assist in moving beyond the illusion of a representative democracy. Furthermore, with reference to Hart's ladder (in Whitty \& Wisby, 2007), it is clear that learner participation in both schools needs to move towards learner-initiated decision-making where learners initiate the process and invite adults to join them in decision-making.

In keeping with the need for greater involvement of learners in democratic school governance, a comment made by many of the participants is pertinent: training of all stakeholders, including learner representatives, is necessary. The principal at Excel Secondary School said:

I as a school [sic] can do a little bit more in terms of training of those learners ... but there is still room to get to that level or stage. A lot of it is about exposure. I mean, it's always about improving things.

In other words, the principal recognises that the learners require training. Similarly, Bush and Heystek (2003) as well as Tsotetsi, Van Wyk and Lemmer (2008) recommend training or capacity building for stakeholder representatives on the SGB. Van Wyk (2004) found that the training SGB members received did influence the competence of the stakeholder representatives. Essentially, the training of all SGB members requires attention and it is crucial that the training should not only be done on a once-off basis. Instead, there should be a series of training sessions with the focus on developing essential skills such as deliberation.

\title{
7.2 Shared decision-making
}

All the respondents affirmed the need for shared decision-making in a democratic school. A similar key word used by respondents to imply shared decision-making was collective decision-making. This is evident in the following response by a parent representative at Excel Secondary School:

At Excel Secondary collective decision-making, which is a principle of democracy, is upheld. By this I mean that there is shared decision-making and consultation before decisions are taken.

From the aforementioned response, it is evident that the parent had some idea of shared decision-making as a principle of democracy. The principals at the sampled schools appeared to embrace the notion of shared decisionmaking and this was also evident in our observations. During our observation of a school management team (SMT) meeting at Red Star Secondary School where the post-provisioning norms (PPN) were being discussed, we witnessed how the principal sought input from all the management members. The principal as well as the other management members often used the pronouns 'we' and 'us', suggesting that they were part of a team and implying that there was a feeling of togetherness. In other words, the principal tried to create a sense of unity or oneness. In his attempts to get inputs from other individuals, the principal often said, "Tell us what you are thinking". This shows that the principal was attempting to get others involved in the decision-making process. At one point the principal stated, "We need to sort this 
issue out..." These statements suggest a notion of shared responsibility with regard to decision-making. This view is corroborated by Bennis and Graves (2009) who maintain that democratic schools generally centre around shared decision-making. This approach stimulates the open communication which is necessary in democratic environments. Moreover, democracy, which requires participation by all, thrives on communication and more specifically on the open exchange of views (Bäckman \& Trafford, 2007).

The School Management Plan (2000:2) at Red Star Secondary School reads, "... it is vitally important that the whole staff be represented in the processes of decision-making ... members of staff represent themselves and they contribute directly to decision-making". This document discloses on paper the expectation of as well as a commitment to shared decision-making. Through observations at the school and by means of interviews with participants, it was clear that this notion did, to an extent, translate into practice. Moreover, during staff briefings, the SMT meeting and SGB meetings at both schools it was observed that there was open and free-flowing communication. At briefing sessions the staff was free to pitch their ideas. However, the teacher representatives at both schools felt the need for shared decisionmaking but agreed that there were times when decisions had to be taken unilaterally. A teacher at Excel Secondary School explained:

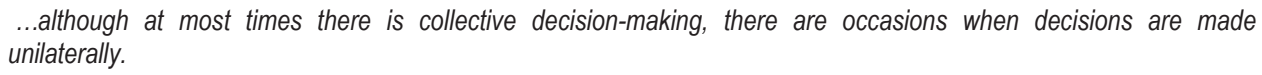

At Red Star Secondary School a teacher representative stated:

I think there are times when maybe the principal would have to make a decision in a kind of autocratic way for the running of the school.... You cannot for every single issue be democratic...

These teachers stated that there were occasions when decisions had to be made unilaterally; however, this did not seem to be an issue for them. Unilateral decision-making suggests that there is no consultation and this is reminiscent of the traditional practices of principals. However, it is necessary to point out that there may be instances where the principal will have to make a unilateral decision, but this should be the exception rather than the rule. The principal at Excel Secondary School stated emphatically, "I can tell you, there were more instances when I was democratic than undemocratic." Even though there were instances when the principals made unilateral decisions it was clear that, in general, shared decision-making was authentic. Shared decision-making contributes towards a shared vision and purpose.

\section{Conclusions}

The study aimed to investigate authentic experiences of SGBs and to analyse their functioning as a tool for promoting democracy in schools. Data were gathered through interviews, observations and document reviews. The findings revealed that democratic practices existed at both schools and that democratic processes were characterised by shared decision-making and the acknowledgement of the rights of individuals, representation, participation and equality. Two structures for promoting democracy in schools were found to be in existence as each school had a functioning SGB and RCL. Both structures were found to be functioning effectively and they were contributing to democracy in the schools. The election of membership of both these structures was done democratically through a structured voting process. The responses of both learner and teacher representatives did not only provide insight into the functioning of the democratic structures in the schools but, most importantly, indicated that these individuals had an understanding of representative democracy. The learner, teacher and parent representatives understood that they represented a larger constituency and they also understood their role and function. Participants at both schools made reference to collective decision-making, collaboration and voting as democratic processes. However, some issues were highlighted that could impact negatively on democratic values in the schools.

Although the learner voice was represented at both schools, learner participation in crucial issues was limited. Yet, participants were of the opinion that the RCLs, which are solely learner initiatives, were structures that contributed to democracy in their schools. Therefore, although more could be done with regard to the inclusion of the learner voice in major decision-making, the researchers were convinced that democratic participation at both schools was effective and not reduced to merely establishing formal decision-making structures like the SGB and RLC. There was a lively democracy at both researched schools.

Linked to apartheid ideologies is the notion of power relations. Participants were of the opinion that relationships 
between learners and some teachers could hinder democratic school practices. In other words, reference was made to hierarchical power relations between learners and teachers. Lack of effective learner participation could be explained through unequal power relations issues. With unequal power relations between learners and teachers, learners assume passive roles and are expected to submissively conform to what adults think is best for them. On the other hand, teachers are viewed by most parents and learners as figures of authority and as such are deemed much more knowledgeable than parents and learners. The researchers also observed at SGB meetings that there was minimal participation by the learner representatives. It may be deduced that learners were consulted and informed but they were not involved in shared decision-making with adults. This is in line with what existing research suggests, namely that both parents and learners seem to be excluded from policy formulation in schools (Mncube \& Harber, 2009).

Another constraining factor to the process of developing more democratic schools is the issue of the training of SGB members. Participants indicated that training stakeholders required urgent attention. In a nutshell, the researchers noted that parent and learner governors lacked the necessary skills required to execute the duties assigned to them; thus the need for on-going training was identified.

Democracy depends on the participation of people and accordingly democratic schools require the participation of all stakeholders. Another factor hindering effective parental participation was parent apathy. The findings of this study suggest that parent apathy hinders their democratic participation. Factors contributing to parent apathy include the lack of time to attend meetings, transport problems, and communication issues. In addition, the lack of participation could be attributed to the apartheid era when parental and learner participation in school governance was limited or did not exist at all (Squelch, 1999). Although parents are provided with the opportunity to become involved in the running of the school, the majority do not seize this opportunity for the reasons outlined above.

In conclusion, it was observed that although the learner voice was represented at both schools, learner participation in crucial issues was limited. Yet, participants were of the opinion that the RCLs, which are solely learner initiatives, were structures that contributed to democracy in their schools. Therefore, although more could be done with regard to the inclusion of the learner voice in major decision-making, the researchers were convinced that democratic participation at both schools was functioning and that it was not reduced to merely establishing formal decision-making structures like the SGB and RLC. There was a lively spirit of democracy at both researched schools, which augurs well for the future.

\section{Recommendations}

Based on the above findings, the study recommends that all teachers, learners and parent representatives on the SGB be trained in skills such as deliberation, debate, dialogue, and conflict management. Furthermore, training or capacity building related to advocacy skills and leadership development should be provided for all members of the SGB, including the teachers. In order to improve learner participation on SGBs, learners should also be involved in shaping the policies of the school - particularly the code of conduct - which would in turn assist in moving beyond the illusion of a representative democracy. Also, schools need to move towards learner-initiated decision-making where learners initiate the process and invite adults to join them in decision-making. The findings also pointed to the shortage of teachers trained in democratic ways of operating in the school and classroom. Through such training, teachers will learn ways of working democratically in both the whole school and the classroom. In a nutshell, there is a need to train teachers in democratic schooling. Participants felt that some teachers in the school were still influenced by the ideologies with which they had been indoctrinated in the apartheid era. Better learner, parental and staff involvement in establishing school policy and decision-making will lead to more genuine community involvement and more effective and efficient school management.

\section{References}

Apple M W \& Beane J A 2007. Schooling for democracy. Principal Leadership, 8(2): 35-38.

Bäckman E \& Trafford B 2007. Democratic governance of schools. Strasbourg: Council of Europe Publishing.

Bennis D \& Graves I 2009. Democratic education. Alternative Education Resource Organisation. Available at http://www.educationrevolution.org/demschool.html. Accessed 21 March 2009.

Bush T \& Heystek J 2003. School governance in the New South Africa. Compare, 33(2): 127-138.

Carr P 2008a. Educating for democracy: with or without social justice. Teacher Education Quarterly Fall: 117-136.

Carr P 2008b. Educators and education for democracy: moving beyond "thin" democracy. Inter-American Journal of Education and Democracy, 1(2): 147-165. 
Datta A 1984. Education and society: sociology of African education. London: Macmillan.

Dewey J 1916. Democracy and education: an introduction to the philosophy of education. New York: MacMillan.

Dewey J 1939. Freedom and culture. New York: Capricorn Books.

Frank S \& Huddleston T 2009. Schools for society. Learning and democracy in Europe. A handbook of ideas for action. London: Alliance Publishing Trust.

Goodlad JI Mantle-Bromley C \& Goodlad SJ 2004. Education for everyone: agenda for education in a democracy. San Francisco: Jossey-Bass.

Grant C 2006. Emerging voices on teacher leadership: some South African views. Educational Management Administration and Leadership, 34(4): 511-532.

Grant C Gardner K Kajee F Moodley R \& Somaroo S 2010. Teacher leadership: a survey analysis of KwaZulu-Natal teachers' perceptions. South African Journal of Education, 40(3): 401-419.

Harber C 1997a. Education, democracy and political development in Africa. Brighton: Sussex Academic Press.

Harber C 1997b. International developments and the rise of education for democracy. Compare, 27(2): 179-191.

Held D 2006. Models of democracy. (3rd ed.). Cambridge: Polity Press.

Karlsson J \& Mbokazi S 2005. Transformation of the South African schooling system: exploring the mutability of school ethos during South Africa's first post-apartheid decade. Johannesburg: The Centre for Education Policy Development.

Mncube VS 2009. Perceptions of the principal's role in democratic school governance in South Africa. Journal of Educational Administration and History, 41(1): 29-43.

Mncube VS \& Harber C 2009. Learners' involvement in democratic governance of schools: a comparative study between Britain and South Africa. British Journal of Educational Studies, 8 (1): 33- 57.

Mncube VS \& Harber CR 2010. Chronicling educator practices and experiences in the context of democratic schooling and quality education in South Africa. International Journal of Educational Development, 30(6): 614-624.

Mncube VS \& Harber CR 2013. Learners' democratic involvement in school governing bodies in South Africa: making the voice of the voiceless. SA-eDUC, 10(1): 1-24.

Mncube VS Harber CR \& du Plessis P 2011. Effective school governing bodies: parental involvement, training and issues of school effectiveness in two provinces of South Africa. Acta Academica, 43(2): 54-81.

O'Hair MJ McLaughlin HJ \& Reitzug UC 2000. Foundations of democratic education. Belmont: Wadsworth/Thompson Learning.

Print M Ørnstrøm S \& Nielsen HS 2002. Education for democratic processes in schools and classrooms. European Journal of Education, 37(2): 193-210.

Republic of South Africa 1996a. Constitution of the Republic of South Africa. Pretoria: Government Printer.

Republic of South Africa 1996b. The organisation, governance and funding of schools, Education White Paper 2. Pretoria: Government Printer.

Republic of South Africa 1996c. The South African Schools Act, 84 (1996). Pretoria: Government Printer.

Republic of South Africa 2007. Education Laws Amendment Act, 2007 (Act No. 31 of 2007) (ELAA). Johannesburg: Polity.

Singh R 2006. Principals' perspectives of shared school governance in the Stanger District of KwaZulu-Natal. MEd dissertation. Pretoria: University of South Africa.

Squelch J M 1999. Governance of education. In E Lemmer (ed.). Contemporary education: global issues and trends. Sandton: Heinemann: 128-146.

Talisse RB 2007. A pragmatist philosophy of democracy. New York: Routledge.

Trafford B 2008. Democratic schools: towards a definition. In J Arthur, I Davies \& C Hahn (eds). The Sage handbook of education for citizenship and democracy. London: Sage: 410-423.

Tsotetsi S Van Wyk N \& Lemmer E 2008. The experience of and need for training of school governors in rural schools in South Africa. South African Journal of Education, 28(3): 385-400.

Van Wyk N 2004. School governing bodies: the experiences of South African educators. South African Journal of Education, 24(1): 4954.

Whitty G \& Wisby E 2007. Real decision making? School councils in action. Institute of Education: University of London.

Young IM 2000. Inclusion and democracy. Oxford: Oxford University Press. 